Article

\title{
Understanding the Variability of West African Summer Monsoon Rainfall: Contrasting Tropospheric Features and Monsoon Index
}

\author{
Akintomide Afolayan Akinsanola ${ }^{1,2} * \mathbb{1}$ and Wen Zhou ${ }^{2}$ (D) \\ 1 Department of Geography, University of Georgia, Athens, GA 30602, USA \\ 2 Guy Carpenter Asia-Pacific Climate Impact Centre, School of Energy and Environment, City University of \\ Hong Kong, Hong Kong SAR, China; wenzhou@cityu.edu.hk \\ * Correspondence: akinsanola@uga.edu
}

Received: 10 February 2020; Accepted: 19 March 2020; Published: 22 March 2020

\begin{abstract}
West African Summer Monsoon (WASM) rainfall exhibits large variability at interannual and decadal timescales, causing droughts and floods in many years. Therefore it is important to investigate the major tropospheric features controlling the WASM rainfall and explore its potential to develop an objective monsoon index. In this study, monthly mean reanalysis data from the National Centers for Environmental Prediction/National Center for Atmospheric Research (NCEP/NCAR) and monthly rainfall data from three gridded observations during the 65-year period of 1950-2014 were employed. Dry and wet rainfall years were identified using a standardized precipitation index. In a composite analysis of wet and dry years, the dynamical features controlling the WASM exhibit an obvious contrast between these years, and a weaker (stronger) African Easterly Jet (Tropical Easterly Jet) is observed during the wet years. Also, a well-developed and deep low-level westerly flow at about $850 \mathrm{hPa}$ is evident in wet years while an obvious reversal is observed in dry years. Considering this, the main regions of the two easterly jet streams and low-level westerly wind are proposed for objectively defining an effective WASM index (WASMI). The results indicate that the WASMI defined herein can reflect variations in June-September rainfall over West Africa. The index exhibits most of the variabilities observed in the rainfall series, with high (low) index values occurring in the 1950-1960s (1970-1980s), suggesting that the WASMI is skilled in capturing the respective wet and dry rainfall episodes over the region. Also, the WASMI is significantly correlated $(r=0.8)$ with summer monsoon rainfall, which further affirms that it can indicate not only variability but also the intensity of WASM rainfall.
\end{abstract}

Keywords: precipitation; African Easterly Jet; Tropical Easterly Jet; atmospheric circulation

\section{Introduction}

The West African Monsoon (WAM) is a large-scale circulation feature that is characterized by seasonal reversal in wind direction in the lower levels of the atmosphere [1,2]. The WAM is an essential part of global circulation and one of the most energetic components of Earth's climate system. It is notable for its complexity as a result of strong scale interaction between different elements of the atmospheric circulation [3]. For instance, the African Easterly Jet (AEJ), located in the mid-troposphere with a core around $600-700 \mathrm{hPa}$ and maximum zonal wind reaching $10 \mathrm{~m} \mathrm{~s}^{-1}$, is one of the most prominent features of the WAM. The combined baroclinic-barotropic instability of the AEJ gives rise to the African Easterly Waves (AEWs), a phenomenon that has been identified as a key driver of rainfall patterns and convection [4]. Furthermore, most of the convective rainfall over the region follows the displacement of the Intertropical Discontinuity (ITD), with a mean upward motion reaching the upper 
troposphere around $150 \mathrm{hPa}$ [5]. At this level (i.e., $150 \mathrm{hPa}$ ), there is a Tropical Easterly Jet (TEJ) that is associated with the South Asian monsoon outflow and propagates across West Africa during boreal summer. Additionally, the low-level southwesterly monsoon flow at around $850 \mathrm{hPa}$ is the key driver of moisture from the Atlantic Ocean to the continent. Previous studies have shown that the strength and position of all the above-mentioned circulation features influence not only the amount of rainfall but also its variability [6-10].

The summer months of June-September are usually the wettest in West Africa, accounting for about $80 \%$ of the total annual rainfall [11,12]. This period of heavy rainfall is generally referred to as the West African Summer Monsoon (WASM) season, an important component of the WAM. Over the years, the West African region has experienced large fluctuations in seasonal rainfall [13], with pronounced variability across a range of temporal scales. These range from intraseasonal and seasonal variations that are critical for water resource management, hydroelectric power generation, and rain-fed agriculture [14], to interannual and decadal variabilities that have strong implications for long-term water availability. Notable is the persistent drought over the Sahel in the 1980s, which is the strongest interdecadal climate signal among recent observational records in global monsoon regions [15,16]. An increase in annual rainfall has been reported in recent decades [13], although compared to the long-term mean, a negative anomaly still persists. The wide range of associated socioeconomic impacts of this drought event has led to increased interest in understanding the mechanisms that influence rainfall variability in West Africa [11,13]. Many studies have objectively diagnosed the different causes and mechanisms of this drought episode. For example, [17] associated the prolonged drought with changes in surface albedo and land cover along the southern boundary of the Sahara Desert. Some studies have attributed the event to numerous local and remote forcings, which include variations in anomalous sea surface temperatures (SSTs) [18-21], regional land-atmosphere feedbacks [22], the effect of human activity on surface vegetation and continental land surface conditions [23,24], and large-scale patterns of atmospheric circulation [25,26]. Nevertheless, variation in atmospheric circulation features has been identified as the most crucial driver of this rainfall variability [2,27], as their characteristics differ significantly in typical wet and dry years over the region [28-30]. However, only a few studies have linked the variation of these atmospheric features to the variability of summer monsoon rainfall and the potential of using it as an objective monsoon index.

In order to characterize and quantify the variability of the WASM, it is very important to use a representative variable(s) as an objective measure, if such a variable exists. Consideration of seasonal changes in rainfall and the associated changes in wind regime should form the basis of a monsoon index, although the choice and selection of an index by definition may be somewhat arbitrary, as indicated by [31]. Therefore, applying a meaningful and concise index to characterize monsoon variability can (1) greatly improve the accuracy of seasonal rainfall forecasts over the region, (2) facilitate empirical studies of the relationship between monsoon variability and lower-atmospheric boundary forcing, and (3) further aid objective assessment of the capability of numerical and climate models to reproduce monsoon variability. The use of area-averaged precipitation indices for characterization of WAM intensity has been reported in the literature [32,33], and these indices have proved to be a reliable measure of WAM variability. However, the efficiency of these indices is limited due to the scarcity of high-temporal-resolution quality precipitation series over the region. Recognizing this shortcoming, a few researchers have attempted to build an index of WAM intensity using winds at several tropospheric levels. For example, [29] proposed a monsoon index consisting of the standardized anomaly of the wind modulus at $900 \mathrm{hPa}$ and the zonal component of the wind at $200 \mathrm{hPa},[34$ ] proposed an intensity index using the dynamical normalized seasonality (DNS) of the wind field at $850 \mathrm{hPa}$ within a large domain of West Africa (5-17.5 $\left.\mathrm{N}, 20^{\circ} \mathrm{W}-40^{\circ} \mathrm{E}\right)$, and more recently, [35] developed the African South Westerly Index (ASWI) based on the persistence of low-level southwesterly winds in the region $\left(29^{\circ} \mathrm{W}-17^{\circ} \mathrm{W}\right.$, $\left.7-13^{\circ} \mathrm{N}\right)$. These indices have demonstrated reasonable success over the region in terms of describing seasonal rainfall, but some of the proposed indices are lacking in terms of representing the main dynamics of the WAM, as is obvious in the case of [34,35], and are sometimes inadequate to capture 
the variability of WASM rainfall. Therefore, this study aims to revisit the main tropospheric circulation features controlling WASM rainfall and investigate how these features differ during a typical wet and dry year. Based on this insight, our goal is to propose a new WASM index that will be capable of representing the dynamics of summer monsoon rainfall and also characterizing the variations in summer rainfall over the region.

\section{Data and Methodology}

\subsection{Data}

The monthly rainfall data used in this study consist of datasets from the Climate Research Unit (CRU) Time Series (TS) (CRU TS 4.01) [36], Global Precipitation Climatology Centre (GPCC) version 7 [37], and University of Delaware (UDEL) version 3.01, all at $0.5^{\circ} \times 0.5^{\circ}$. These products are widely used over West Africa owing to their high temporal and spatial resolution, and they have been highlighted as one of the best substitutes for rain-gauge rainfall data over West Africa [12]. Also the monthly pressure level vertical velocity, specific humidity, divergence, and zonal and meridional wind dataset used in this study was obtained from the National Centers for Environmental Prediction (NCEP)/National Center for Atmospheric Research (NCAR) reanalysis dataset [38] at $2.5^{\circ} \times 2.5^{\circ}$. The whole dataset was averaged for the summer months of June-September for the years 1950-2014 and was analyzed over West Africa, as shown in Figure S1. Additionally, we assess the consistency of the WASM index (WASMI) developed herein with the NCEP/NCAR reanalysis by comparing with that generated from (1) the NCEP-U.S. Department of Energy (DOE) AMIP-II reanalysis (NCEP2; [39]), with 2.5 $\times 2.5^{\circ}$ resolution; (2) the European Centre for Medium-Range Weather Forecasts interim reanalysis (ERAI; [40]) at $0.5^{\circ} \times 0.5^{\circ}$; and (3) the Japanese 55-year reanalysis (JRA-55; $1.25^{\circ} \times 1.25^{\circ}$ ) [41] for the common period of $1979-2014$.

\subsubsection{Methodology}

Based on the 65-year time period under study, the standardized rainfall anomaly presented in Figure S2 shows that the region exhibits both interannual and decadal variation with a positive and negative tendency. For instance, there is an increasing rainfall tendency in the 1950s and 1960s and a decrease in the 1970 and 1980s, followed by a fluctuating increase until 2014. On this note, a comprehensive analysis of contrasting dynamical features between the composite wet and dry years was carried out. It should be noted that the wet and dry years used in this study were computed by performing a standardized anomaly of June-September (JJAS) rainfall for the three gridded observations. We defined a new indicator for dry and wet years, referred to herein as multidata dry years (MDDY) and multidata wet years (MDWY), respectively, as presented in Figure 1.

The MDDY (MDWY) is valid if all three gridded observations consistently have a standardized precipitation index (SPI) value of less than (more than) $-0.8(+0.8)$ for a particular year. The \pm 0.8 SPI criterion is chosen to increase the sample size and enable a more robust statistical analysis. With this approach, any conflict among the products relating to wet and dry years over the region is eliminated. Based on the results, we randomly selected eight strong wet years $(1952,1955,1957,1961$, 1962, 1963, 1964, and 1999) and eight strong dry years (1972, 1976, 1982, 1983, 1984, 1986, 1990, and 2002). The composite was computed by averaging the respective events (i.e., wet and dry years), and statistical significance was evaluated using a $t$-test with the significance level set at $95 \%$.

The standardized precipitation index SPI was computed using Equation (1).

$$
\mathrm{SPI}=\frac{X-\bar{X}}{\sigma}
$$

where $X$ is the rainfall series, $\bar{X}$ is the long-term mean, and $\sigma$ is the standard deviation. 
(a) Dry rainfall years

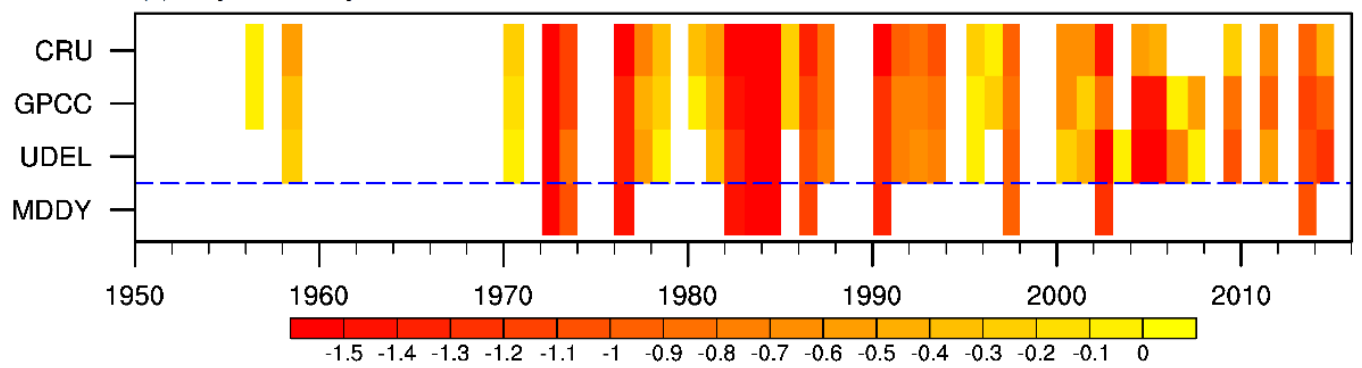

(b) wet rainfall years

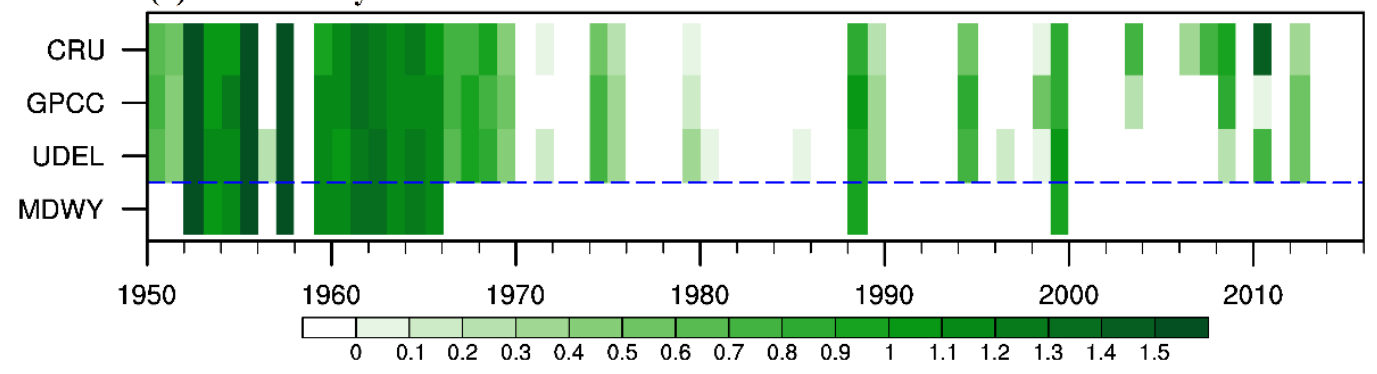

Figure 1. Standardized summer monsoon rainfall anomaly over West Africa for (a) dry years and (b) wet years. The blue line in $(\mathbf{a}, \mathbf{b})$ demarcates the newly developed multidata dry years (MDDY) and multiyear wet years (MDWY) from the observation's series. Abbreviations: CRU (Climate Research Unit Time Series (TS) (CRU TS 4.01)) [36]; GPCC (Global Precipitation Climatology Centre version 7) [37]; and UDEL (University of Delaware version 3.01).

The coefficient of variation (CV) measures the overall variability of the rainfall in the area of interest, calculated using Equation (2). A lower (higher) value of CV indicates less (more) rainfall variability.

$$
\mathrm{CV}=\frac{\sigma}{\mu} \times 100
$$

where $\mu$ is the mean rainfall and $\sigma$ is the standard deviation.

Finally, the vertically integrated moisture flux (Q) used in this study can be expressed as

$$
\mathrm{Q}=\frac{1}{g} \int_{300}^{p_{s}} q V d p
$$

where $g$ is the acceleration due to gravity, $p$ is the pressure, $p_{S}$ is the surface pressure, $q$ is the specific humidity, and $V$ is the wind vector.

\section{Results and Discussion}

\subsection{Spatial and Temporal Distributions of Summer Rainfall over West Africa}

In this section, the climatology of the summer monsoon (June-September) for the years 1950-2014 is discussed alongside the coefficient of variation, and results are presented for the three gridded rainfall observations. During the climatological wet months of JJAS, considerable spatial variation in the seasonal mean rainfall is observed over the subcontinent, as indicated in Figure 2a,c,e. The areas with the highest rainfall can be seen within the Guinea coast $\left(4-8^{\circ} \mathrm{N}, 20^{\circ} \mathrm{W}-20^{\circ} \mathrm{E}\right)$ subregion of West Africa, with a mean rainfall of about $11 \mathrm{~mm} \mathrm{day}^{-1}$. Also observed is that the regions of highest rainfall coincide with regions of high topography (i.e., Fouta Djallon highland, Jos Plateau, and the Cameroonian mountains), and the highest variability as depicted by the coefficient of variation in Figure $2 b, d, f$ is evident within the central Guinea coast subregion (i.e., Cote d'Ivoire, Ghana, Togo, Benin, and western Nigeria). In contrast, the Sahel $\left(11-16^{\circ} \mathrm{N}, 20^{\circ} \mathrm{W}-20^{\circ} \mathrm{E}\right)$ subregion receives comparatively 
little rainfall $\left(\sim 5 \mathrm{~mm} \mathrm{day}^{-1}\right)$. Significant agreement can be found among the three gridded rainfall observations, although with noticeable differences. For instance, the UDEL data exhibit low rainfall when compared to CRU and GPCC. Generally, there is considerable inhomogeneity in the spatial distribution of summer monsoon rainfall over West Africa. The summer rain belt is positioned in a zonal and tilted band between $5^{\circ} \mathrm{N}$ and $15^{\circ} \mathrm{N}$, with rainfall decreasing from south to north (i.e., weaker values are located over the northern Sahel and the Sahara Desert).

(a) CRU mean rainfall

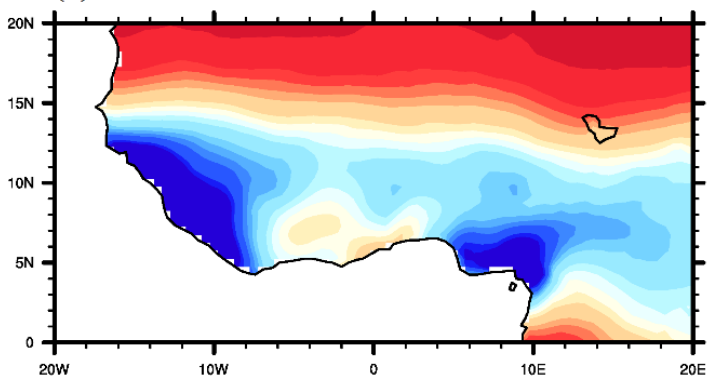

(c) GPCC mean rainfall

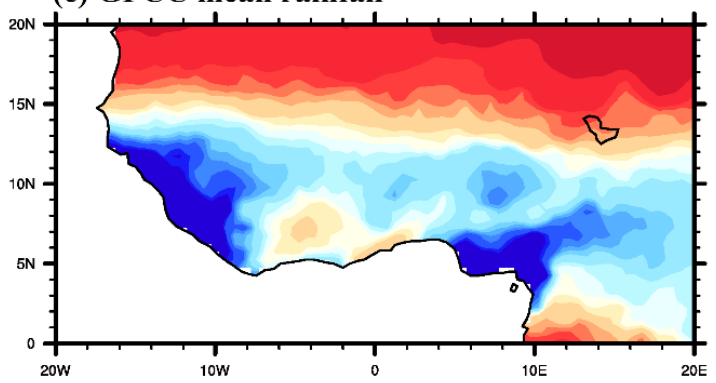

(e) UDEL mean rainfall

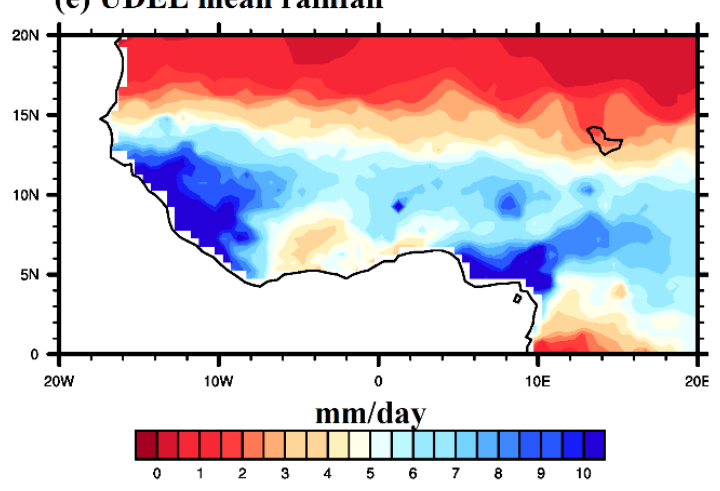

(b) CRU CV

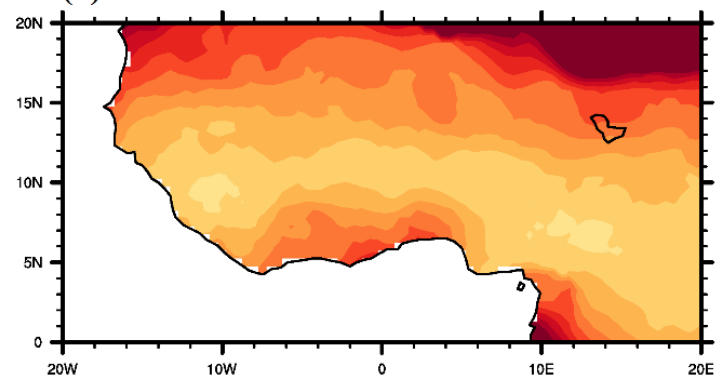

(d) GPCC CV

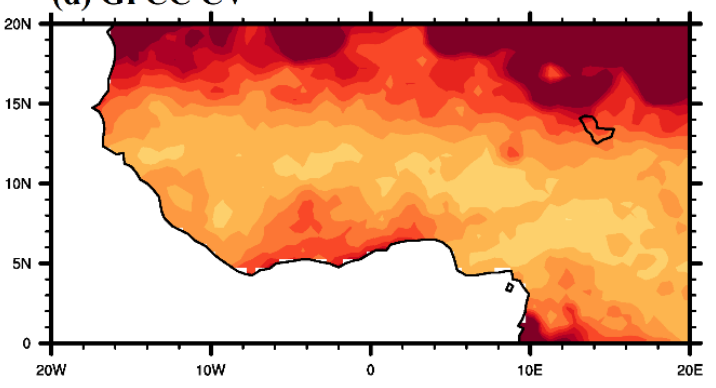

(f) UDEL CV

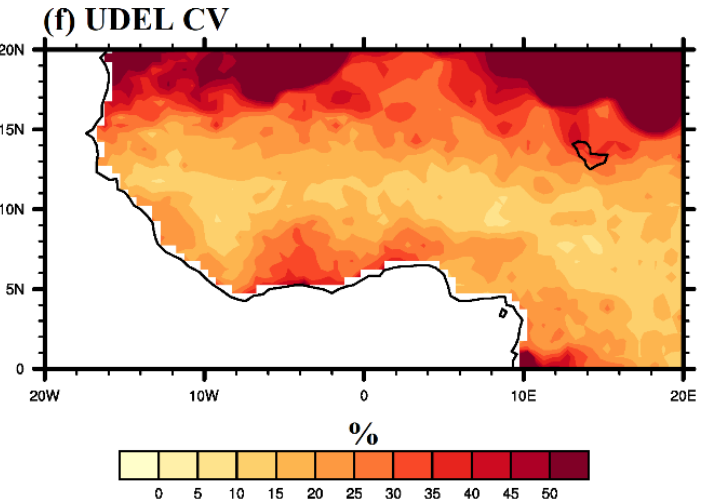

Figure 2. Spatial distribution of June-September (JJAS) rainfall $\left(\mathrm{mm} \mathrm{day}^{-1}\right)$ for $(\mathbf{a}, \mathbf{c}, \mathbf{e})$ mean climatology and $(\mathbf{b}, \mathbf{d}, \mathbf{f})$ coefficient of variation $(\mathrm{CV})$.

\subsection{Mean Climatology of Large-Scale Tropospheric Features Associated with the WASM}

In the summer monsoon season of JJAS, the large-scale tropospheric circulation over West Africa is characterized by a low-level southwesterly flow below the $800 \mathrm{hPa}$ level at $4-15^{\circ} \mathrm{N}$, with a maximum mean wind speed of about $3 \mathrm{~m}^{-1}$. Also, two easterly wind maxima (i.e., jet streams), at the levels of 700 and $150 \mathrm{hPa}$, are referred to as the AEJ and TEJ, respectively. The core of the AEJ is centered at $15^{\circ} \mathrm{N}$ with a maximum mean wind speed of around $10 \mathrm{~m}^{-1}$, and it occurs as a result of the strong meridional surface moisture and temperature gradients between the Sahara and equatorial Africa. It is maintained by the juxtaposition of moist convection to the south and dry convection to the north [42-45]. The upper-tropospheric TEJ, centered at $8^{\circ} \mathrm{N}$, has a maximum mean wind speed of about $16 \mathrm{~m}^{-1}$ and is associated with the upper-level outflow from the Asian monsoon (Figure 3a). 
The development of the TEJ is related to the thermal wind pattern during the Northern Hemisphere summer [46].

(a)
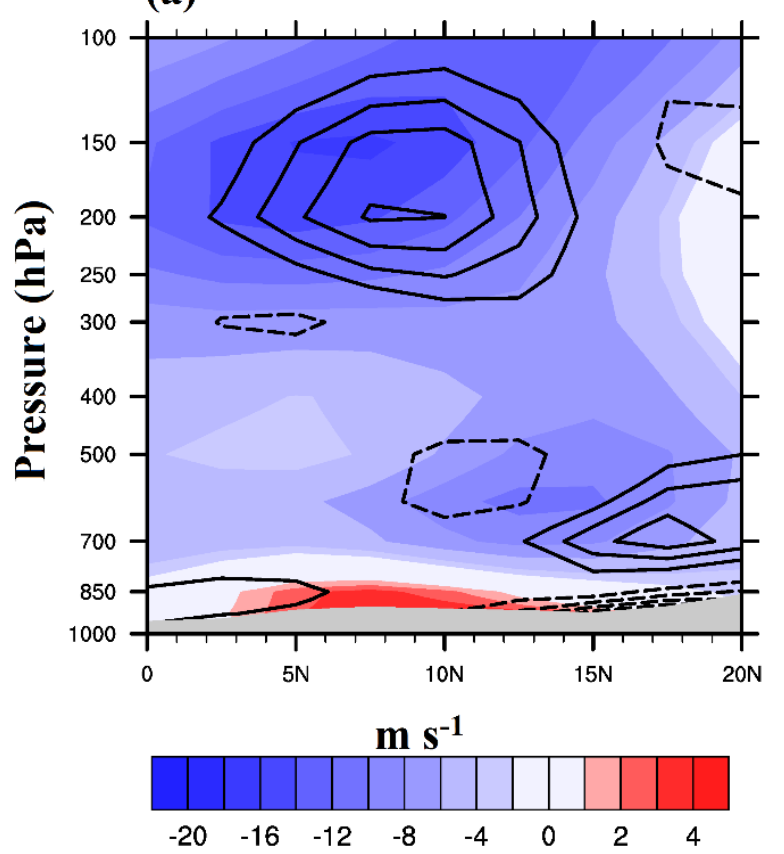

(b)

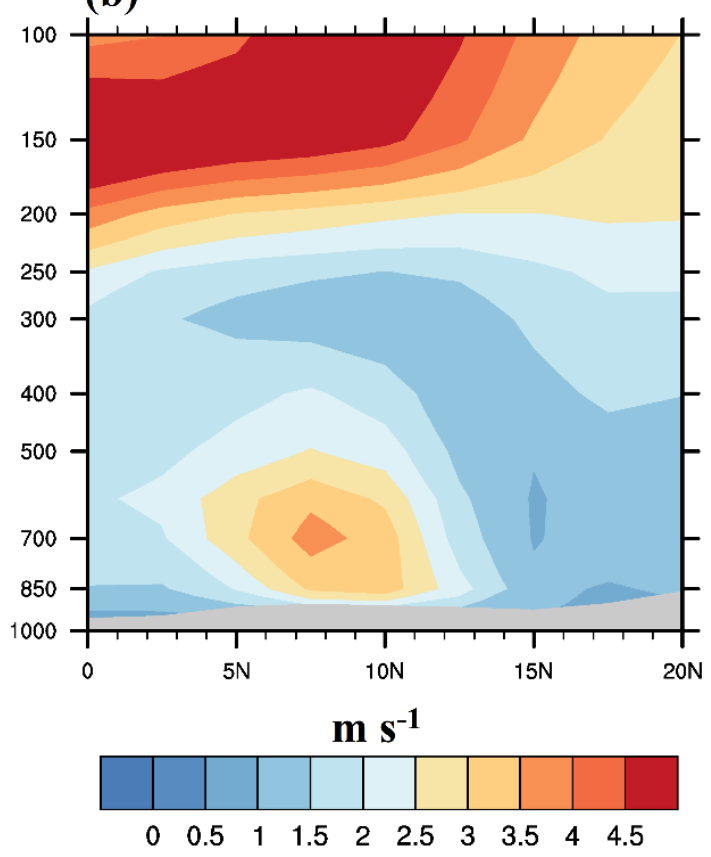

Figure 3. Climatological mean of JJAS (a) zonal wind ( $\mathrm{m} \mathrm{s}^{-1}$; shaded) and divergence ( $\mathrm{m} \mathrm{s}^{-1}$; contours) and (b) standard deviation of zonal wind. Values under the topography are masked gray.

Generally, there are two major areas of strong convergence over West Africa: at low levels between latitude $10^{\circ} \mathrm{N}$ and $20^{\circ} \mathrm{N}$, and also at the 500-650 hPa levels around latitude 8-12 ${ }^{\circ} \mathrm{N}$ within the upper pressure level and south of the AEJ. Strong divergence is observed in the upper troposphere between 150 and $250 \mathrm{hPa}$ around latitude $2-15^{\circ} \mathrm{N}$ and at the mid-tropospheric level of $700 \mathrm{hPa}$ within the Sahel subregion. The areas of divergence in the middle and upper troposphere as shown in Figure 3a coincide respectively with the position of the two easterly jets (i.e., AEJ and TEJ). It is important to state that the levels of 850,700 , and $150 \mathrm{hPa}$, where the major features controlling the WAM are located, exhibit the highest variability, as evident in the climatological mean standard deviation (Figure 3b).

\subsection{Composite Analysis of Contrasting Wet and Dry Years}

In this section, the contrast in WAM dynamics between composite wet and dry years is investigated to try to understand the variability in WAM dynamics. The insight gained should help identify the atmospheric features influencing wet and dry years over West Africa.

Divergence and zonal wind anomaly during wet and dry years: The tropospheric zonal wind has been further analyzed in order to understand its variability and impact on the wet and dry phases of WASM rainfall, with the result presented in Figure 4a,b. In wet years (Figure 4a), the TEJ is significantly stronger than the mean climatology and the AEJ is weaker and situated about $2-3^{\circ}$ farther north, while the low-level westerlies are quite intense and extend well into the mid-troposphere, reaching up to the $800 \mathrm{hPa}$ level. Stronger divergence lies in the anticyclonic shear of the TEJ (i.e., $150 \mathrm{hPa}$ level), especially over the Sahel, implying strong ascent over the subregion. However, at the lower level, anomalous stronger convergence dominates the West African atmosphere. The physical link between the TEJ and rainfall may be the observed upper-level divergence associated with the jet stream, which could enhance rainfall by promoting ascent in the lower level beneath the jet core. 
(a) Zonal wind and divergence (wet years)

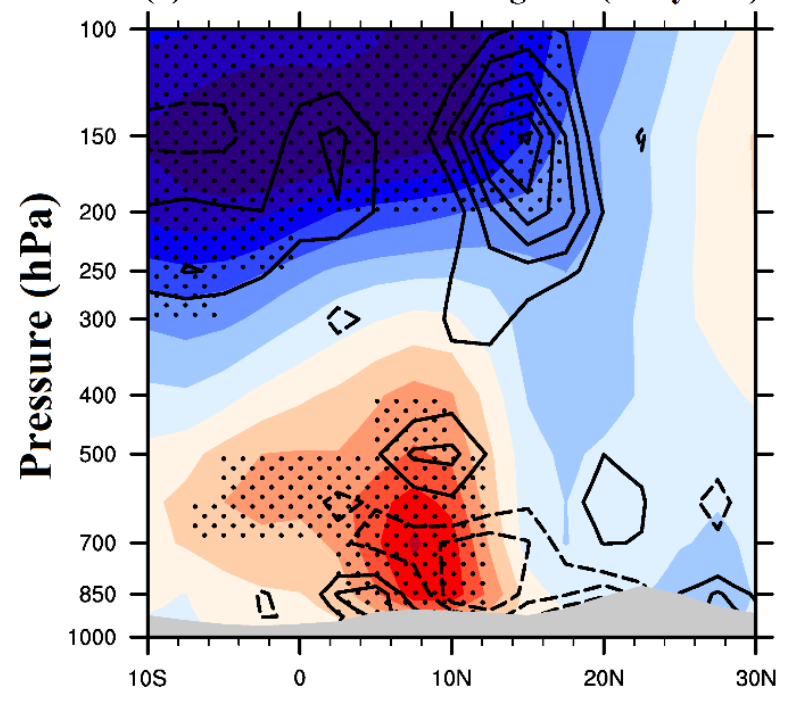

(b) Zonal wind and divergence (dry years)

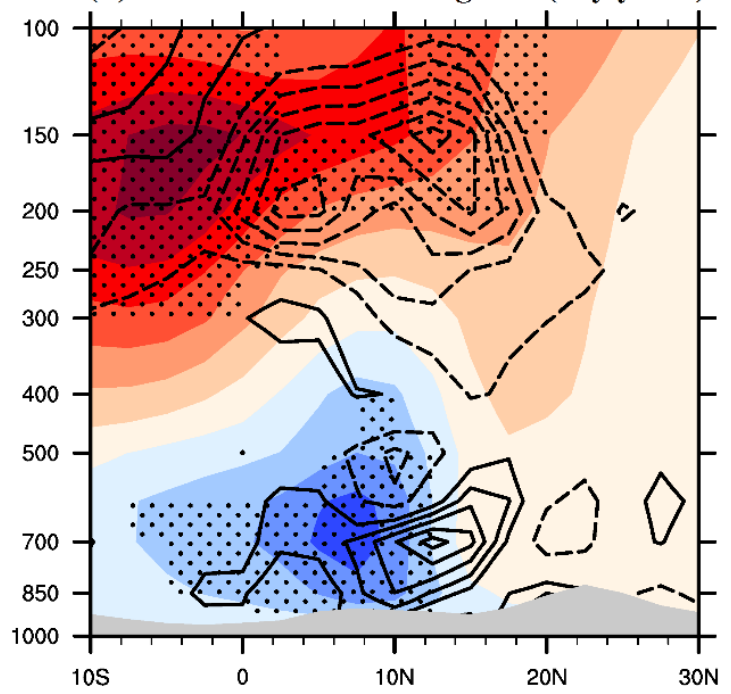

$\mathbf{m ~ s}^{-1}$

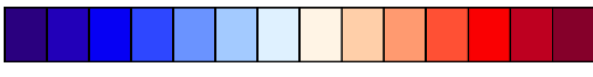

$\begin{array}{lllllllllllll}-6 & -5 & -4 & -3 & -2 & -1 & 0 & 1 & 2 & 3 & 4 & 5 & 6\end{array}$

(c) Meridional wind and omega (wet years)

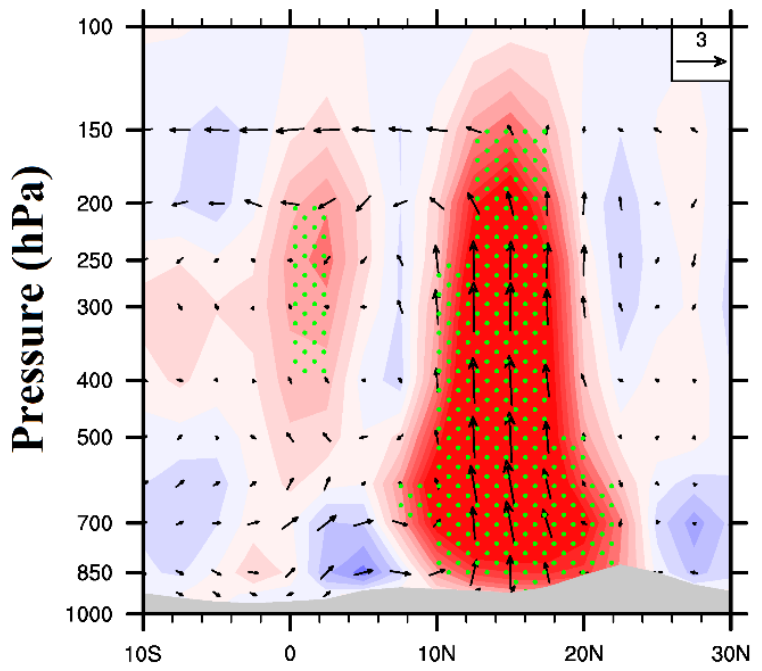

(d) Meridional wind and omega (dry years)

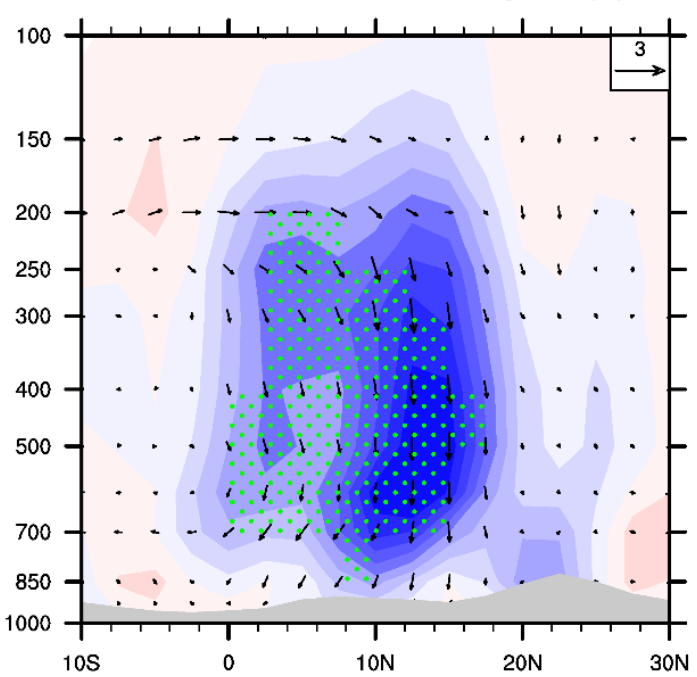

$-100 \times \mathrm{Pa} \mathrm{s}^{-1}$

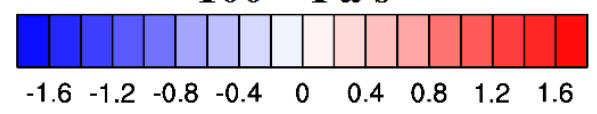

Figure 4. Anomalies of zonal wind (shaded; $\mathrm{m} \mathrm{s}^{-1}$ ) and divergence (contours; $\mathrm{m} \mathrm{s}^{-1}$ ) in (a) wet years and (b) dry years. Latitude-height cross section of Hadley circulation anomalies for (c) wet years and (d) dry years. The circulation consists of meridional $\left(\mathrm{m} \mathrm{s}^{-1}\right)$ and vertical velocity $\left(-100 \times \mathrm{Pa} \mathrm{s}^{-1}\right)$. Values under the topography are masked gray. Stippling indicates regions where anomalies are significant at the $95 \%$ level.

In contrast, dry years (Figure $4 \mathrm{~b}$ ) exhibit a relatively weaker and shallower monsoon flow, and a stronger (weaker) AEJ (TEJ). Also, the upper-level divergence and mid-level convergence are evidently weaker, implying weaker ascent. The bias (figure not shown) emphasizes the importance of the low-level westerly flow and contrasts its strength and vertical extent between the two episodes. The enhanced low-level westerly wind not only displaces the mid-level easterly maximum AEJ northward, but also displaces its core westward. Generally, vertical and horizontal wind shear values 
are stronger in wet years than in dry years, implying stronger combined baroclinic-barotropic instability in wet years. This baroclinicity is stronger particularly over the Sahel subregion, as a result of the northward shift of the AEJ into the Sahel during wet years and its position south of the Sahel in dry years. Therefore, the associated vertical shear and baroclinic instability are crucial in the Sahel in wet years, but completely absent in dry years. The AEJ affects rainfall by creating moisture divergence below the level of condensation, and hence a decrease in rainfall. Our result agrees with the work of $[5,47]$, who reported that the link between the TEJ and rainfall appears to be primarily upper-level divergence associated with the jet core.

Local circulation anomalies: The monsoon strength can also be determined by the strength of the Hadley circulation (north-south circulation). This circulation is represented as a pressure-latitude section of vector winds constructed with meridional wind and vertical velocity anomalies, and averaged over the West African longitudes $\left(20^{\circ} \mathrm{W}-20^{\circ}\right.$ E: Figure $\left.4 \mathrm{c}, \mathrm{d}\right)$. Anomalous strong ascending motion north of $8^{\circ} \mathrm{N}$ and weak descending motion over the southern equatorial region and the Sahara Desert is evident during wet years (Figure 4c). In dry years (Figure 4d) there is a strong descending branch around $2-17^{\circ} \mathrm{N}$ (latitudinal belt of West Africa), which implies suppressed convection (subsidence) through a regional anomalous Hadley circulation, associated with anomalous convergence at the level of the TEJ. These bands of anomalous rising and sinking motion are statistically significant at the 95\% level. Therefore, a strengthened mid-level tendency of the AEJ, a weakening tendency of low-level westerly flow at $850 \mathrm{hPa}$, an upper tropospheric tropical easterly, and a monsoon Hadley-type circulation are associated with weaker WASM rainfall and thus a drier Sahel.

Velocity potential and divergent wind anomalies: The distribution of the velocity potential and divergent wind anomalies at the levels of 150 and $850 \mathrm{hPa}$, which correspond to the upper and lower tropospheric levels and are analyzed for wet and dry composite years, is presented in Figure 5a-d. An anomalous center of convergence is located over West Africa at the lower levels during wet years (Figure $5 b$ ) and extends towards the Asian monsoon region. A strong divergence anomaly is evident at the upper level of $150 \mathrm{hPa}$ (Figure 5a). In contrast, during dry years, an intense convergence anomaly is evident at $150 \mathrm{hPa}$ (Figure 5c) over the study domain, reaching up to the Indian region, while an anomalous low-level divergence is evident (Figure 5d). This obvious modulation of the Walker circulation implies an extension of the anomalous downward motion over West Africa, consistent with the suppression of monsoon convection and the observed weaker monsoon rainfall, which may be one reason for the observed deficit in these years. Generally, the baroclinicity over West Africa, as indicated by the location and centers of convergent and divergent wind anomalies, differs considerably in the contrasting years.

Anomalies of vertically integrated moisture flux and divergence: To assess the underlying physical processes in the evolution of moisture sources and transport, the distribution of the vertically integrated (1000-300 hPa) moisture flux and moisture divergence anomalies, which also represent total precipitable water for the summer monsoon season (JJAS) during wet and dry composite years, is shown in Figure 6. The equatorial Atlantic Ocean is the main channel remotely supplying water vapor to West Africa.

During the anomalous wet years (Figure 6a), strengthened southwestern water vapor transport, which brings more moisture from the Atlantic Ocean and converges over the Sahel, leads to more precipitation in these subregions. The convergence of water vapor flux has an evident center over the Sahel, while the Guinea coast subregion experiences moisture divergence. In contrast, during dry years (Figure 6b), the inland penetration of the moisture flux is less pronounced as a result of a weaker southwesterly, there is strong moisture divergence over the Sahel, and weaker moisture convergence can be observed around the southern Guinea coast and northeastern Nigeria. Generally, moisture produced by surface evaporation over the northern tropical Atlantic Ocean and the Guinea coast is transported inland by low-level westerly winds, thereby increasing water vapor anomalies in the Sahel subregion. Hence, the atmospheric circulation plays a crucial role in increasing warm temperature anomalies by transporting moisture into the Sahel and sustaining the water vapor. 
(a) Velocity potential and divergent wind at $150 \mathrm{hPa}$ (wet years)

(b) Velocity potential and divergent wind at $850 \mathrm{hPa}$ (wet years)
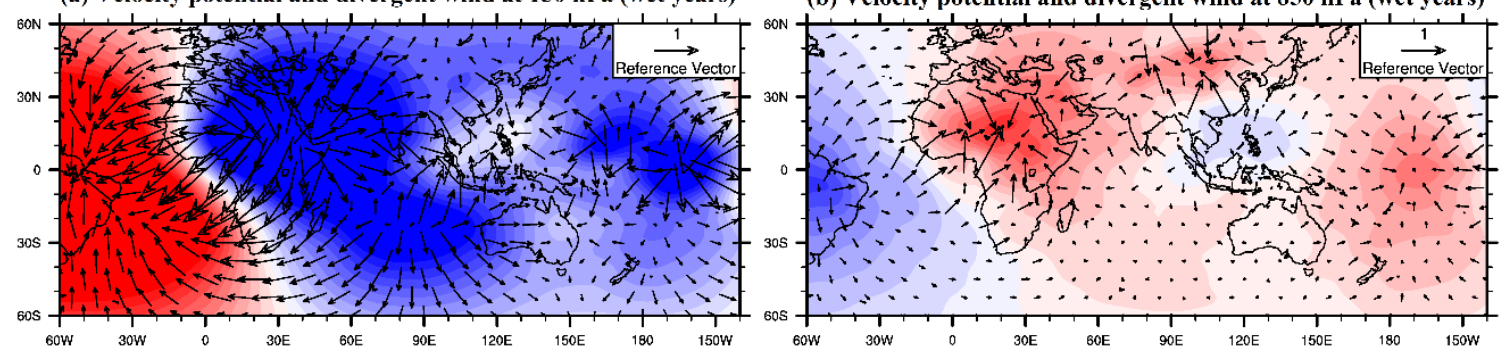

(c) Velocity potential and divergent wind at $150 \mathrm{hPa}$ (dry years)

(d) Velocity potential and divergent wind at $850 \mathrm{hPa}$ (dry years)

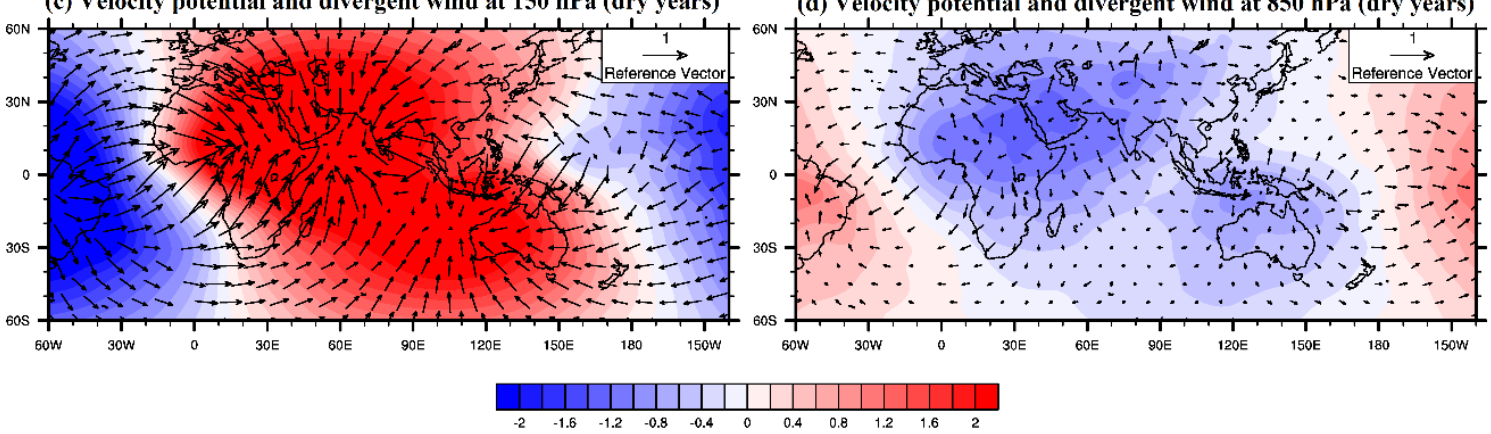

Figure 5. Velocity potential $\left(10^{-5} \mathrm{~m}^{2} \mathrm{~s}^{-1}\right.$; shaded) and divergent wind anomalies $\left(\mathrm{m} \mathrm{s}^{-1}\right.$; vectors) for wet $(\mathbf{a}, \mathbf{b})$ and dry $(\mathbf{c}, \mathbf{d})$ years at $150 \mathrm{hPa}(\mathbf{a}, \mathbf{c})$; and $850 \mathrm{hPa}(\mathbf{b}, \mathbf{d})$.
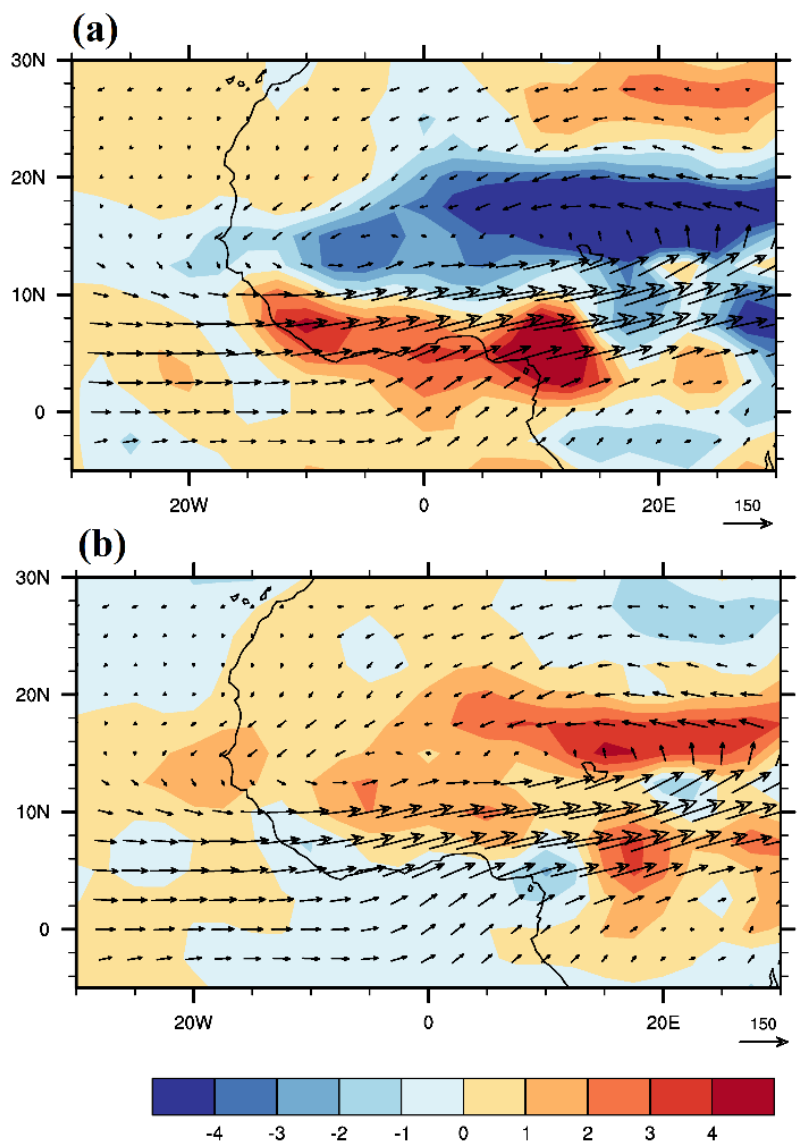

Figure 6. Vertically integrated moisture flux (vectors; $\mathrm{kg} \mathrm{m}^{-1} \mathrm{~s}^{-1}$ ) and moisture divergence (shading; $10^{-4} \mathrm{~kg} \mathrm{~m}^{-2} \mathrm{~s}^{-1}$ ) anomalies for (a) wet and (b) dry years. 


\subsection{The West African Summer Monsoon Index (WASMI)}

Results presented in previous sections revealed how the major tropospheric features contrast in typical wet and dry years over West Africa. In this section, we explore the potential of these important tropospheric circulation features controlling the WASM by using them to develop an objective summer monsoon index. A correlation analysis is performed between the area-averaged WASM rainfall from CRU observations and NCEP1 zonal wind (Figure 7). The highest negative and positive correlation values that are statistically significant at the 95\% level are found at the levels of the TEJ, AEJ, and low-level westerly wind (LLWW), which further emphasizes the importance of these features to WASM rainfall. In view of this, we propose an index for the West African summer monsoon (WASMI), based on multiple regression analysis (regression of WASM rainfall and zonal wind is presented in Figure S3). This index is easy to compute and represents the basic important dynamics of the West African monsoon reported in this work. Analyses from this study showed that not only the low-level westerly flow and TEJ are crucial for WASM activity, as emphasized by [29,34], but also the easterly jet located at $700 \mathrm{hPa}$ (i.e., the $\mathrm{AEJ}$ ).

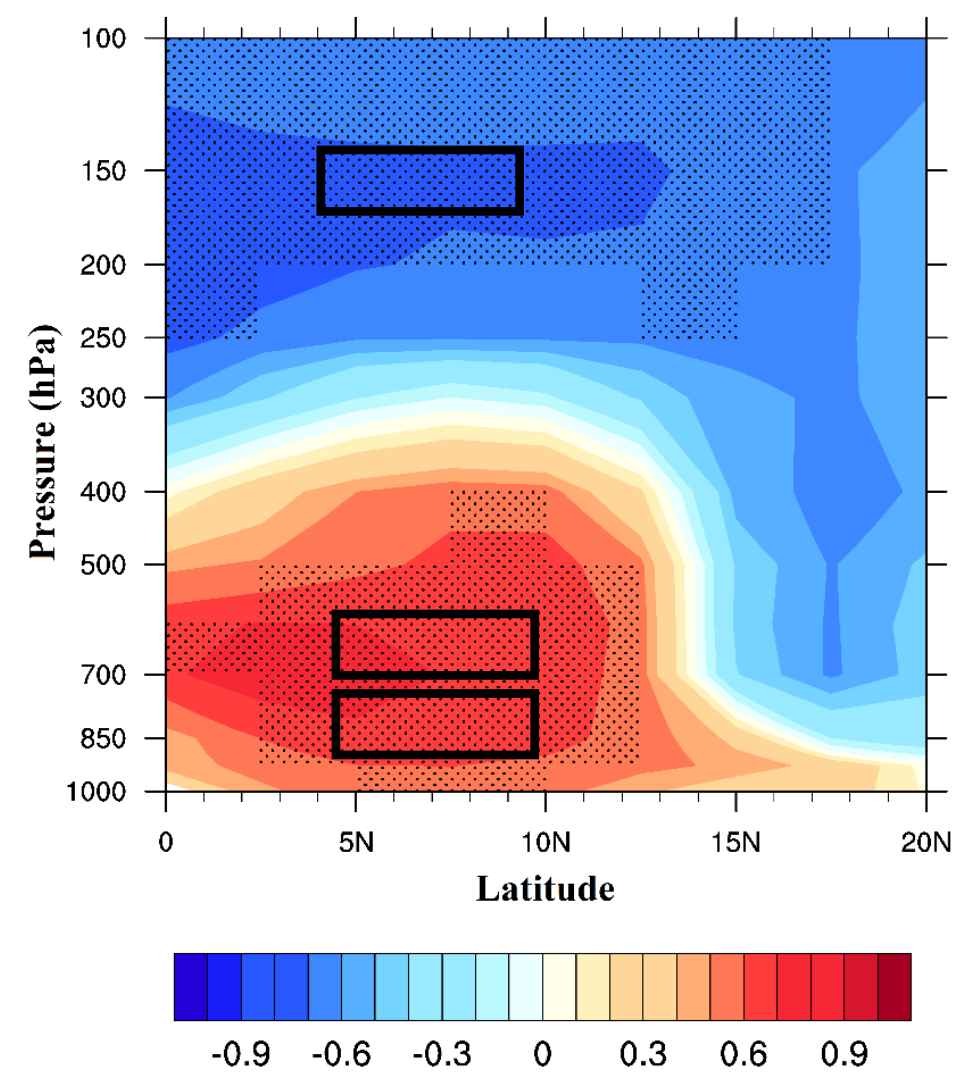

Figure 7. Correlation between JJAS zonal wind and area-averaged summer monsoon rainfall over West Africa $\left(4-16^{\circ} \mathrm{N}, 20^{\circ} \mathrm{W}-20^{\circ} \mathrm{E}\right)$. Stippling indicates regions where changes are significant at the $95 \%$ level.

Therefore, we use the zonal speed of the two easterly winds (i.e., AEJ and TEJ) and the LLWW as an intensity index of the WASM, called the WASMI:

$$
\mathrm{WASMI}=0.08 \mathrm{U}_{850(\mathrm{LLWW})}+0.1 \mathrm{U}_{700(\mathrm{AEJ})}-0.04 \mathrm{U}_{150(\mathrm{TEJ})}+6.2
$$

where $\mathrm{U}_{850}$ is the zonal wind at the $850 \mathrm{hPa}$ level, $\mathrm{U}_{700}$ is the zonal wind at $700 \mathrm{hPa}$, and $\mathrm{U}_{150}$ is the zonal wind at $150 \mathrm{hPa}$ averaged between latitude $4^{\circ} \mathrm{N}$ and $10^{\circ} \mathrm{N}$ and longitude $20^{\circ} \mathrm{W}$ and $20^{\circ} \mathrm{E}$. 
The newly defined WASMI can capture most of the variability of WASM rainfall (Figure 8). The WASMI shows a great ability to capture some interannual and decadal variation of WASM rainfall. For instance, the rainfall series exhibits two noticeable episodes: the wet period between the 1950s and 1960s and the dry years between the 1970s and 1980s. In line with the rainfall series, the WASMI exhibits these variabilities, with high (low) index values occurring in the 1950-1960s (1970-1980s), implying its potential to capture the respective wet and dry years over the region. Although during the 1960s, some noticeable discrepancies are observed in the WASMI when compared to the rainfall series, this may be partly due to the well-known poor quality of reanalysis data in the early years. The overall result implies that for an abundant rainfall regime over the region, the low-level westerly flow and strength of the TEJ must be higher than the climatological mean, while the strength of the AEJ must show a relative decrease. The WASMI also exhibits a positive statistically significant correlation with the three gridded rainfall observations $(\mathrm{r} \sim 0.8)$, as presented in Figure 9 and Table 1, which further emphasizes its ability to reproduce a significant part of WASM rainfall variability. It is important to state that the newly developed WASMI is poorly correlated with summer rainfall in major parts of the Guinea coast subregion, which may be due to the region's complexity associated with orographic and Atlantic Ocean SST influences. This poor relationship is also evident in previous indices (Figure S4). The newly developed index compares well with previous indices, especially that of [29,34], in capturing the overall variabilities in the last 65 years. The index of [35] shows differences with other indices and exhibits a relatively poor performance with lower correlation coefficient values (Table 1); it also lacks the capability to capture most of the variabilities observed in the rainfall series. Overall, the newly developed WASMI performs better than existing indices (Table 1), which may be attributed to better representation of the important features of the WASM.

Finally, we investigate the reproducibility of other commonly used reanalyses by comparing the index developed with the NCEP1 reanalysis with that developed with NCEP2, Era-Interim, and JRA55. Figure 10 presents the time series of the WASMI developed using different reanalysis datasets for the common period of 1979-2014. Results show that the NCEP1, NCEP2, and JRA55 datasets are fairly consistent with each other, although with different magnitudes, and are more suitable for defining the WASMI, based on the correlation analysis (Table 2).

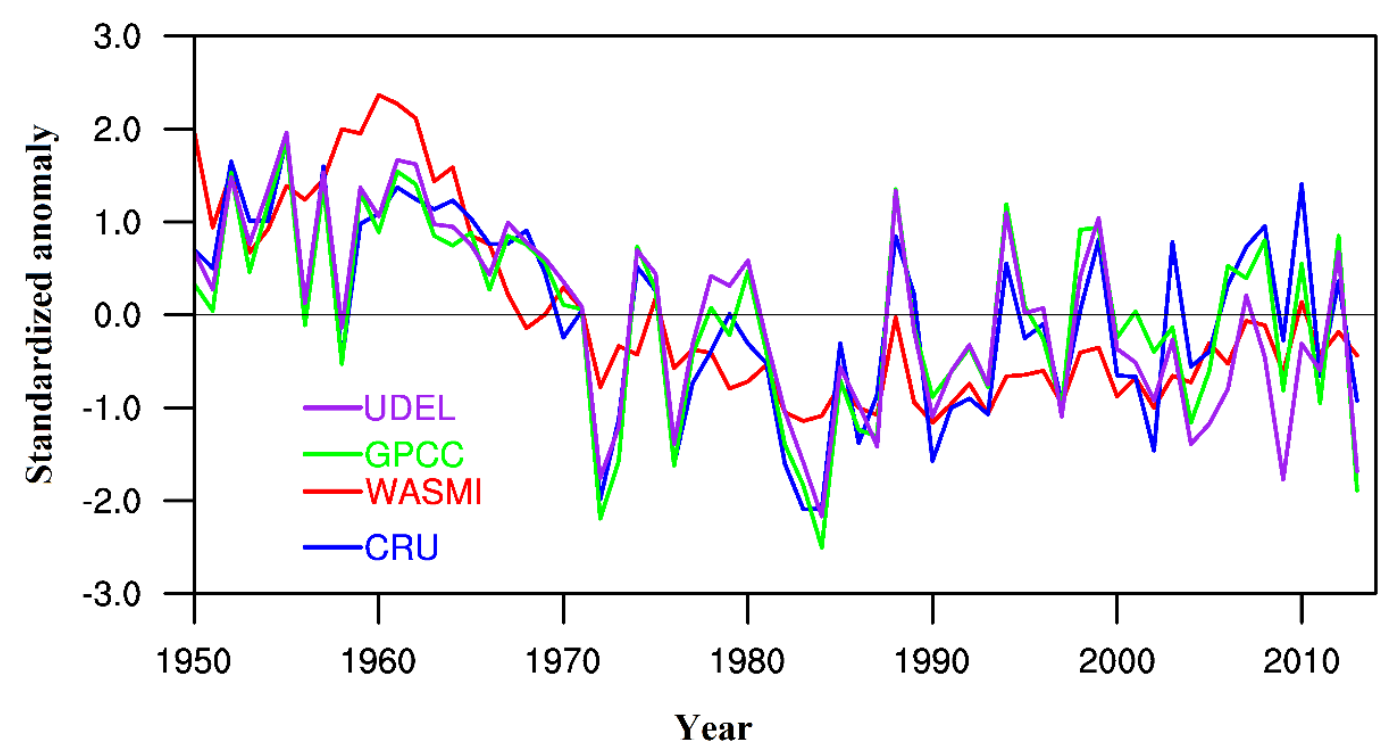

Figure 8. Time series of the standardized anomaly of the WASMI and the three gridded rainfall observations. 
(a) WASMI corr with CRU rainfall

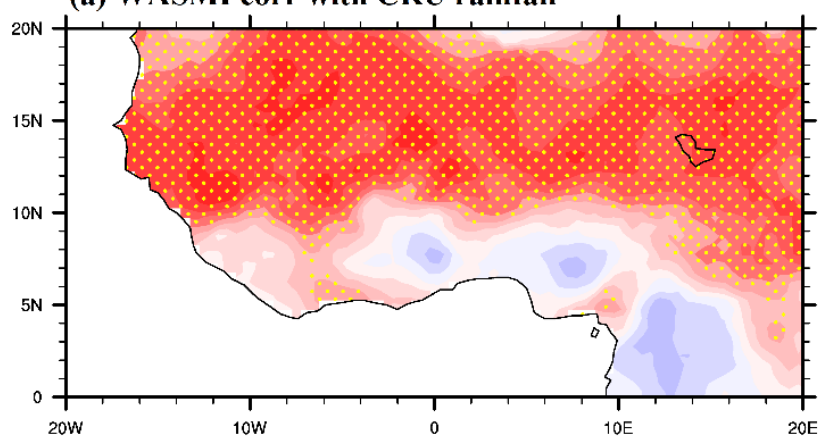

(b) WASMI corr with GPCC rainfall

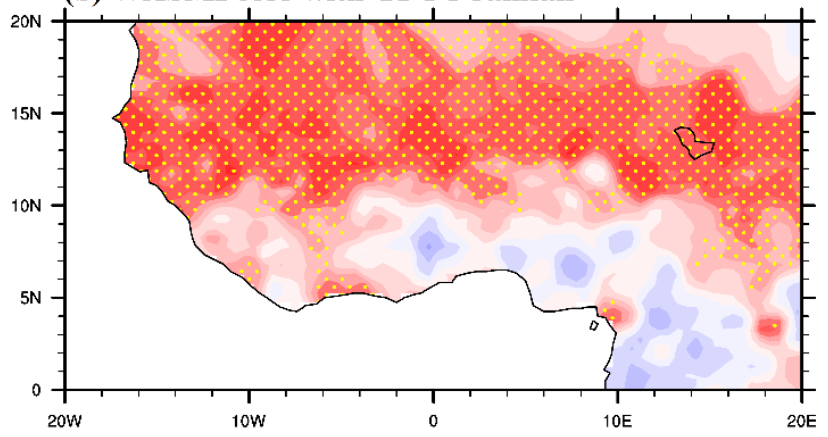

(c) WASMI corr with UDEL rainfall

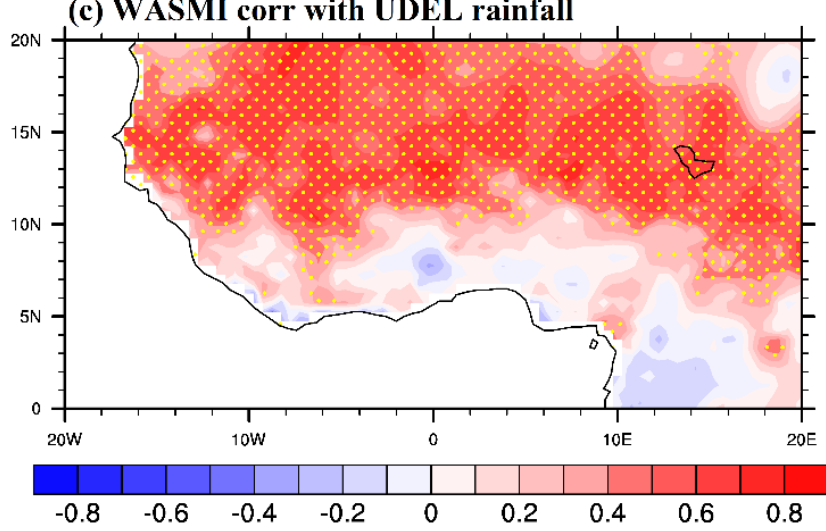

Figure 9. Spatial correlation between WASMI and JJAS rainfall of (a) CRU, (b) GPCC, and (c) UDEL. Stippling indicates regions where changes are significant at the $95 \%$ level.

Table 1. Correlation coefficient values between various indices and rainfall datasets.

\begin{tabular}{ccccc}
\hline & WASMI & CRU & GPCC & UDEL \\
\hline West African Summer Monsoon Index, WASMI & 1.0 & 0.76 & 0.78 & 0.80 \\
\hline (Gallego et al. 2015 [35]; African South Westerly Index, ASWI) & 0.79 & 0.59 & 0.60 & 0.55 \\
\hline (Fontaine et al. 1995 [29]; Fontaine) & 0.97 & 0.70 & 0.71 & 0.71 \\
\hline (Li and Zeng 2002 [34]; Li_Zeng) & 0.94 & 0.63 & 0.65 & 0.64 \\
\hline
\end{tabular}

Table 2. Correlation coefficient values between WASMI generated from the NCEP1 reanalysis and those generated from other data sources.

\begin{tabular}{lccc}
\hline & WASMI (NCEP2) & WASMI (Era-Interim) & WASMI (JRA55) \\
\hline WASMI (NCEP 1) & 0.97 & 0.60 & 0.70 \\
\hline
\end{tabular}




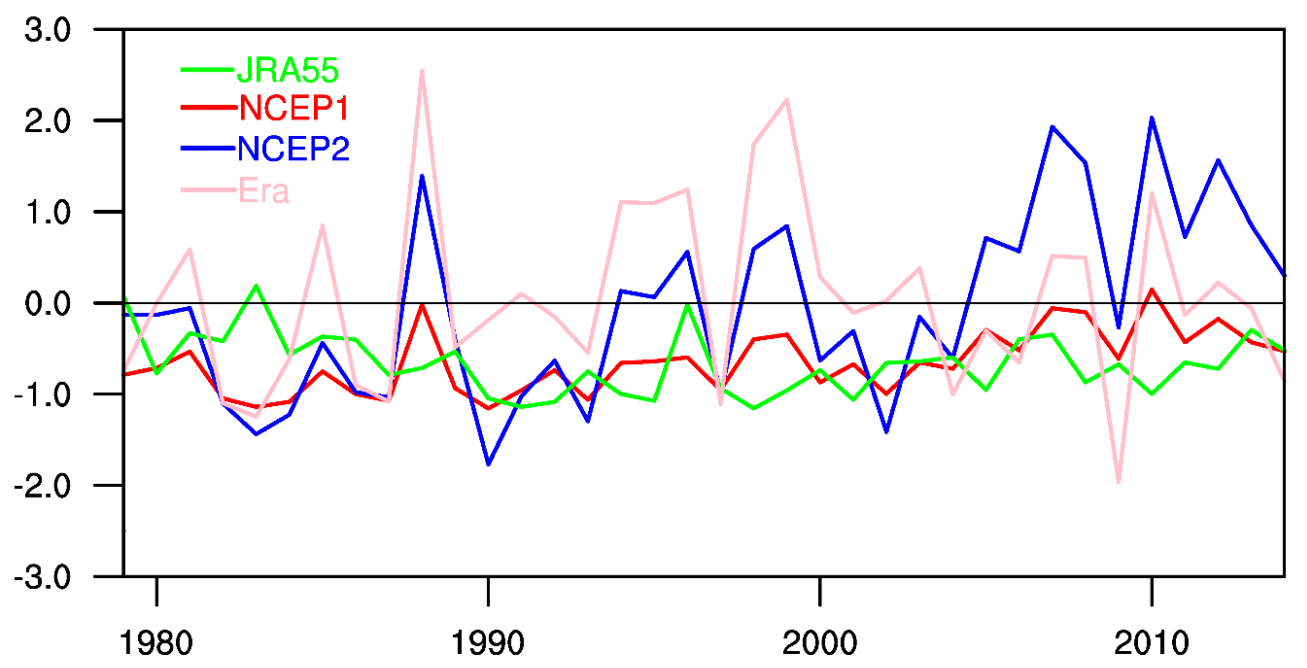

Figure 10. Time series of the standardized anomaly of the WASMI generated using different reanalysis products. Abbreviations: JRA55 (Japanese 55-year reanalysis) [41]; NCEP1 (National Centers for Environmental Prediction (NCEP)/National Center for Atmospheric Research (NCAR) reanalysis) [38]; NCEP2 (NCEP-U.S. Department of Energy (DOE) AMIP-II reanalysis) [39]; and ERA (European Centre for Medium-Range Weather Forecasts interim reanalysis) [40].

\section{Summary and Conclusions}

The results of this study show an obvious contrast between wet and dry JJAS rainfall years. During the wet years, the upper-level TEJ and low-level westerly flow are characterized by strengthened and deeper flows in concomitance with a weakened and northward shift of the mid-level AEJ. The strengthened TEJ during this period is associated with strong upper-level divergence and thus promotes ascent in the lower and mid-troposphere. The resultant combined baroclinic-barotropic instability, especially over the Sahel subregion, which occurs as a result of the weakened and northward shift of the AEJ, is crucial for an enhanced monsoon (i.e., wetter West Africa). Similarly, the reduction in the speed of the AEJ during this period is associated with weaker kinetic and moist static energy (figures not shown). In fact, studies have also shown that the extraction of mean kinetic energy from the AEJ by the African easterly wave during wet years contributes significantly to the reduction in its speed [48]. In contrast, during dry years, a weakened TEJ and low-level westerly flow coupled with a strengthened and southward-positioned AEJ is observed. Since a weaker upper-level TEJ is not sufficient to promote vertical ascent, moisture divergence coupled with sinking motion is observed in the majority of the study area.

Based on the variation of these important tropospheric features associated with WASM rainfall, a simple yet effective index is proposed in this study using 65 years of NCEP/NCAR reanalysis data. The West African summer monsoon index (WASMI) considers not only the zonal easterly winds at the 150 and $700 \mathrm{hPa}$ levels but also the low-level westerly wind at $850 \mathrm{hPa}$ in West Africa. The rainfall averaged over the whole West Africa domain is used as an example to demonstrate the detailed application of the WASMI. Results of the correlation coefficient analysis between the summer monsoon rainfall and the WASMI indicate a strong positive correlation $(r=0.8)$, which is statistically significant at the $95 \%$ confidence level. This implies that the WASMI is capable of explaining part of the rainfall variability over the region. In addition, the WASMI shows great skill in capturing the variations of WASM rainfall adequately. For instance, the rainfall series exhibits two noticeable episodes: the wet period occurring between the 1950s and 1960s and the dry years between the 1970s and 1980s. In line with the rainfall series, the WASMI exhibits these combined interannual and decadal variabilities, with high (low) index values occurring in the 1950-1960s (1970-1980s), implying its potential in capturing the respective wet and dry years over the region. The physical mechanism of the WASMI suggests that for wet years, the strength and intensity of the Tropical Easterly Jet at $150 \mathrm{hPa}$ and the low-level westerly 
wind at $850 \mathrm{hPa}$ must be somewhat higher than the climatological mean, while that of the African Easterly Jet at $700 \mathrm{hPa}$ must be lower than the climatological mean by a few orders of magnitude. This performance observed in the WASMI may be attributed to a better representation of the important features of the WASM rainfall. Hence, this index would be a good tool for studying and monitoring the WASM variability and changes. The applicability of the newly developed WASMI will require further investigation.

Supplementary Materials: The following are available online at http://www.mdpi.com/2073-4433/11/3/309/s1, Figure S1: (a) Study domain showing West African topography and the regions designated as Guinea coast (A), Savannah (B), and Sahel (C), Figure S2: Standardized JJAS rainfall anomaly over West Africa from 1950-2014, Figure S3: Regression between JJAS zonal wind and area-averaged summer monsoon rainfall over West Africa $\left(4-16^{\circ} \mathrm{N}, 20^{\circ} \mathrm{W}-20^{\circ} \mathrm{E}\right)$. Stippling indicates regions where changes are significant at the $95 \%$ level, Figure S4: Spatial correlation between previous indices and JJAS rainfall of (a) CRU, (b) GPCC, and (c) UDEL. Stippling indicates regions where changes are significant at the 95\% level, Figure S5: Time series of the standardized anomaly of the WASMI and other indices.

Author Contributions: The study idea and plan were conceived by A.A.A. and W.Z. Calculations, analysis, and visualizations were carried out by A.A.A., and both authors discussed the results and decided on the final version. All authors have read and agreed to the published version of the manuscript.

Funding: This work is supported by National Nature Science Foundation of China Grant 41675062, and the Research Grants Council of the Hong Kong Special Administrative Region, China (Project No. CityU 11335316 and 11305715). The first author is a recipient of a research studentship provided by the City University of Hong Kong (CityU).

Acknowledgments: We are grateful to the services that have operated the CRU, GPCC, UDEL, NCEP1, NCEP2, Era-Interim, and JRA55 datasets.

Conflicts of Interest: The authors declare no conflict of interest.

\section{References}

1. Akinsanola, A.A.; Zhou, W. Projection of West African summer monsoon rainfall in dynamically downscaled CMIP5 models. Clim. Dyn. 2019, 53, 81-95. [CrossRef]

2. Akinsanola, A.A.; Zhou, W. Dynamic and thermodynamic factors controlling increasing summer monsoon rainfall over the West African Sahel. Clim. Dyn. 2019, 52, 4501-4514. [CrossRef]

3. Sylla, M.B.; Diallo, I.; Pal, J.S. West African monsoon in state-of the-art regional climate models. In Climate Variability—Regional and Thematic Patterns; Tarhule, A., Ed.; Books on Demand: Norderstedt, Germany, 2013; ISBN 980-953-307-816-3.

4. Diedhiou, A.; Janicot, S.; Viltard, A.; de Felice, P. Evidence of two regimes of easterly waves over West Africa and the tropical Africa. Geophys. Res. Lett. 1998, 25, 2805-2808. [CrossRef]

5. Nicholson, S.E. A revised picture of the structure of the "monsoon" and land ITCZ over West Africa. Clim. Dyn. 2009, 32, 1155-1171. [CrossRef]

6. Janicot, S. Impact of warm ENSO events on atmospheric circulation and convection over the tropical Atlantic and West Africa. Ann. Geophys. 1997, 15, 471-475. [CrossRef]

7. Akinsanola, A.A.; Ogunjobi, K.O. Evaluation of present-day rainfall simulations over West Africa in CORDEX regional climate models. Environ. Earth Sci. 2017, 76, 366. [CrossRef]

8. Redelsperger, J.; Diongue, A.; Diedhiou, A.; Ceron, J.; Diop, M.; Gueremy, J.; Lafore, J. Multi-scale description of a Sahelian synoptic weather system representative of the West African monsoon. Q. J. R. Meteorol. Soc. 2002, 128, 1229-1257. [CrossRef]

9. Mohr, K.I.; Thorncroft, C.D. Intense convective systems in West Africa and their relationship to the African easterly jet. Q. J. R. Meteorol. Soc. 2006, 132, 163-176. [CrossRef]

10. Nicholson, S.E. On the factors modulating the intensity of the tropical rainbelt over West Africa. Int. J. Climatol. 2009, 29, 673-689. [CrossRef]

11. Omotosho, J.B.; Abiodun, B.J. A numerical study of moisture build-up and rainfall over West Africa. Meteorol. Appl. 2007, 14, 209-225. [CrossRef]

12. Akinsanola, A.A.; Ogunjobi, K.O.; Ajayi, V.O.; Adefisan, E.A.; Omotosho, J.A.; Sanogo, S. Comparison of five gridded precipitation products at climatological scales over West Africa. Meteorol. Atmos. Phys. 2017, 129, 669-689. [CrossRef] 
13. Nicholson, S. Land surface processes and Sahel climate. Rev. Geophys. 2000, 38, 117-139. [CrossRef]

14. Lebel, T.; Diedhiou, A.; Laurent, H. Seasonal cycle and inter-annual variability of the Sahelian rainfall at hydrological scales. J. Geophys. Res. 2003, 108. [CrossRef]

15. Ward, N.M. Diagnosis and short-lead time prediction of summer rainfall in tropical North Africa at interannual and multi-decadal timescales. J. Clim. 1998, 11, 3167-3191. [CrossRef]

16. Trenberth, K.E.; Smith, L.; Qian, T.; Dai, A.; Fasullo, J. Estimates of the global water budget and its annual cycle using observational and model data. J. Hydrometeorol. 2007, 8, 758-769. [CrossRef]

17. Charney, J.G. Dynamics of deserts and drought in the Sahel. Q. J. R. Meteorol. Soc. 1975, 101, $193-202$. [CrossRef]

18. Folland, C.K.; Palmer, T.N.; Parker, D.E. Sahel rainfall and worldwide sea temperatures, 1901-85. Nature 1986, 320, 602-607. [CrossRef]

19. Janicot, S.; Trzaska, S.; Poccard, I. Summer SAHEL-ENSO teleconnection and decadal time scale SST variations. Clim. Dyn. 2001, 18, 303-320. [CrossRef]

20. Lu, J.; Delworth, T. Oceanic forcing of the late 20th century Sahel drought. Geophys. Res. Lett. $2005,32$. [CrossRef]

21. Sahu, N.; Behera, S.K.; Ratnam, J.V.; Da Silva, R.V.; Parhi, P.; Duan, W.; Yamagata, T.; Takara, K.; Singh, R.B. El Nino Modoki connection to extremely-low streamflow of the Paranaiba River in Brazil. Clim. Dyn. 2014, 42, 1509-1516. [CrossRef]

22. Xue, Y.; Shukla, J. The influence of land-surface properties on Sahel climate. Part I: Desertification. J. Clim. 1993, 6, 2232-2245. [CrossRef]

23. Wang, G.; Eltahir, E.A.B. Ecosystem dynamics and the Sahel drought. Geophys. Res. Lett. 2000, $27,795-798$. [CrossRef]

24. Clark, D.B.; Xue, Y.K.; Harding, R.J.; Valdes, P.J. Modeling the impact of land surface degradation on the climate of tropical North Africa. J. Clim. 2001, 14, 1809-1822. [CrossRef]

25. Nicholson, S.E.; Grist, J.P. A conceptual model for understanding rainfall variability in the West African Sahel on interannual and interdecadal timescales. Int. J. Clim. 2001, 21, 1733-1757. [CrossRef]

26. Jenkins, G.S.; Gaye, A.T.; Sylla, M.B. Late 20th century attribution of drying trends in the Sahel from the Regional Climate Model (RegCM3). Geophys. Res. Lett. 2005, 32. [CrossRef]

27. Sanogo, S.; Fink, A.H.; Omotosho, J.A.; Ba, A.; Redl, R.; Ermert, V. Spatio-temporal characteristics of the recent rainfall recovery in West Africa. Int. J. Climatol. 2015, 35, 4589-4605. [CrossRef]

28. Newell, R.E.; Kidson, J.W. African mean wind changes between Sahelian wet and dry periods. J. Climatol. 1984, 4, 27-33. [CrossRef]

29. Fontaine, B.; Janicot, S.; Moron, S.V. Rainfall anomaly patterns and wind field signals over West Africa in August (1958-1989). J. Clim. 1995, 8, 1503-1510. [CrossRef]

30. Grist, J.P.; Nicholson, S.E. A study of the dynamic factors influencing the rainfall variability in the West African Sahel. J. Clim. 2001, 14, 1337-1359. [CrossRef]

31. Wang, B.; Fan, Z. Choice of South Asian summer monsoon indices. Bull. Am. Meteorol. Soc. 1999, 80, 629-638. [CrossRef]

32. Dai, A.; Lamb, P.J.; Trenberth, K.E.; Hulme, M.; Jones, P.D.; Xie, P. The recent Sahel drought is real. Int. J. Climatol. 2004, 24, 1323-1331. [CrossRef]

33. Nicholson, S.E.; Dezfuli, A.K.; Klotter, D. A two-century precipitation dataset for the continent of Africa. Bull. Am. Meteorol. Soc. 2012, 93, 1219-1231. [CrossRef]

34. Li, J.P.; Zeng, Q.C. A unified monsoon index. Geophys. Res. Lett. 2002, 29. [CrossRef]

35. Gallego, D.; Ordóñez, P.; Ribera, P.; Peña-Ortiz, C.; García-Herrera, R. An instrumental index of the West African Monsoon back to the nineteenth century. Q. J. R. Meteorol. Soc. 2015, 141, 3166-3176. [CrossRef]

36. Harris, I.; Jones, P.D.; Osborn, T.J.; Lister, D.H. Updated high-resolution grids of monthly climatic observations-The CRU TS3.10 Dataset. Int. J. Climatol. 2014, 34, 623-642. [CrossRef]

37. Schneider, U.; Ziese, M.; Meyer-Christoffer, A.; Finger, P.; Rustemeier, E.; Becker, A. The new portfolio of global precipitation data products of the Global Precipitation Climatology Centre suitable to assess and quantify the global water cycle and resources. Proc. Int. Assoc. Hydrol. Sci. 2017, 374, 29-34. [CrossRef]

38. Kalnay, E.; Kanamitsu, M.; Kistler, R.; Collins, W.; Deaven, D.; Gandin, L.; Iredell, M.; Saha, S.; Zhu, Y.; Zhu, Y.; et al. The NCEP/NCAR 40-Year Reanalysis Project. Bull. Am. Meteorol. Soc. 1996, 77, 437-471. [CrossRef] 
39. Kanamitsu, M.; Ebisuzaki, W.; Woollen, J.; Yang, S.-K.; Hnilo, J.J.; Fiorino, M.; Potter, G.L. NCEP-DOE AMIP-II Reanalysis (R-2). Bull. Am. Meteorol. Soc. 2002, 83, 1631-1643. [CrossRef]

40. Dee, D.P.; Uppala, S.M.; Simmons, A.J.; Berrisford, P.; Poli, P.; Kobayashi, S.; Bechtold, P.; Andrae, U.; Bauer, P.; Healy, S.B.; et al. The ERA-Interim reanalysis: Configuration and performance of the data assimilation system. Q. J. R. Meteorol. Soc. 2011, 137, 553-597. [CrossRef]

41. Kobayashi, S.; Ota, Y.; Harada, Y.; Ebita, A.; Moriya, M.; Onoda, H.; Onogi, K.; Kamahori, H.; Endo, H.; Miyaoka, K.; et al. The JRA-55 reanalysis: General specifications and basic characteristics. J. Meteorol. Soc. Jpn. 2015, 93, 5-48. [CrossRef]

42. Cook, K.H. Generation of the African Easterly Jet and its role in determining West African precipitation. J. Clim. 1999, 12, 1165-1184. [CrossRef]

43. Thorncroft, C.D.; Blackburn, M. Maintenance of the African Easterly Jet. Q. J. R. Meteorol. Soc. 1999, 125, 763-786. [CrossRef]

44. Sylla, M.B.; Gaye, A.T.; Jenkins, G.S.; Pal, J.S.; Giorgi, F. Consistency of projected drought over the Sahel with changes in the monsoon circulation and extremes in RegCM3 projections. J. Geophys. Res. 2010, 115. [CrossRef]

45. Akinsanola, A.A.; Ogunjobi, K.O.; Gbode, I.E.; Ajayi, V.O. Assessing the capabilities of three regional climate models over CORDEX Africa in simulating West African summer monsoon precipitation. Adv. Meteorol. 2015. [CrossRef]

46. Hastenrath, S. Climate Dynamics of the Tropics; Kluwer Academic Publisher: Norwell, MA, USA, 1990.

47. Nicholson, S.E.; Grist, J.P. The seasonal evolution of the atmospheric circulation over West Africa and equatorial Africa. J. Clim. 2003, 16, 1013-1030. [CrossRef]

48. Cornforth, R.J.; Hoskins, B.J.; Thorncroft, C.D. The impact of moist processes on the African easterly jet-African easterly wave system. Q. J. R. Meteorol. Soc. 2009, 135, 894-913. [CrossRef]

(C) 2020 by the authors. Licensee MDPI, Basel, Switzerland. This article is an open access article distributed under the terms and conditions of the Creative Commons Attribution (CC BY) license (http://creativecommons.org/licenses/by/4.0/). 